\title{
PEMANFAATAN LIMBAH KULIT PISANG MENJADI PANGANAN OLAHAN KRIPIK PEDAS
}

\author{
Rifni Novitasari, S.Tp., MP \\ Dosen Teknologi Pangan Faperta UNISI \\ rifninovi@gmail.com
}

\begin{abstract}
Abstrak
Pisang merupakan salah satu komoditi buah tropis yang cukup berpotensi di Indonesia termasuk di Kabupaten Indragiri Hilir, Provinsi Riau. Selama ini masyarakat hanya meman-faatkan buah dan jantung pisang sebagai olahan panganan, sedangkan kulit pisang hanya menjadi limbah olahan produk. Padahal kulit pisang tersebut mengandung karbohidrat $18,5 \%$, air 68,90\%, sejumlah vitamin $\mathrm{C}$, beragam vitamin B kompleks diantaranya B6, lemak, lutein, anti oksidan, kalsium, minyak nabati, serat, serotonin dan protein yang cukup. Dengan teknologi pengolahan pangan yang sederhana, kulit pisang ini dapat diolah menjadi kripik kulit pisang pedas yang dapat menjadi makanan cemilan keluarga yang memiliki nilai gizi dan otomatis dapat mengurani limbah organik serta mendatangkan pendapatan tersendiri bagi keluarga.
\end{abstract}

\section{PENDAHULUAN}

Buah pisang banyak dihasilkan di Kabupaten Indragiri Hilir, yang produksinya meningkat dari tahun ke tahun. Produksi buah pisang pada tahun 2006 adalah sebesar 10.662 ton (Website Resmi Pemerintahan Riau, 2010), meningkat pada tahun 2007 menjadi 542,635 ton, meningkat lagi pada tahun 2008 diketahui luas areal panen adalah seluas 293,67 Ha dengan total produksi 3.122,93 ton (Indragiri Hilir dalam Angka, 2010), dan akhir 2011 luas areal $584.784 \mathrm{Ha}$ dengan total produksi buah pisang sebesar 33.651,85 Kw (Badan Pusat Statistik Indragiri Hilir, 2012).

Menurut Basse (2000) jumlah dari kulit pisang cukup banyak, yaitu kira- kira $1 / 3$ dari buah pisang yang belum dikupas. Kandungan unsur gizi kulit pisang cukup lengkap, seperti karbohidrat, lemak, protein, kalsium, fosfor, zat besi, vitamin B, vitamin C dan air. Unsur-unsur gizi inilah yang dapat digunakan sebagai sumber energi dan antibodi bagi tubuh manusia (Munadjim, 1988). Sedangkan manfaat kulit pisang itu sendiri sangat banyak sekali bagi tubuh manusia, antara lain adalah : untuk menambah rasa mood pada tubuh kita karena kulit pisang mengandung serotonim, pereda rasa nyeri karena kulit pisang mengandung minyak nabati, mengatasi rasa gatal, menghambat pertumbuhan kutil, mempercepat pertumbuhan luka, menghilangkan jerawat . Sedangkan berdasarkan penelitian Fakultas Kedokteran Taichung Chung Shan, Taiwan, memperlihatkan bahwa ekstrak kulit pisang sangat berguna untuk mengurangi gejala depresi dan kesehatan retina mata.

Menurut Rukmana (2001), manfaat kulit pisang bagi kesehatan tubuh adalahikut ; 1) Mengurangi gejala depresi kulit pisang mengandung zat serotonin berupa vitamin B6, yang berfungsi untuk mengembalikan 
transmisi impuls ke syaraf sehingga dapat mengurangi gejala depresi yang berlebihan. 2) Menurunkan kadar kolesterol dalam darah vitamin B6 yang terdapat pada kulit pisang, dapat menjaga kestabilan metabolisme tubuh. Dengan lancarnya metabolisme dalam tubuh, kandungan kolesterol jahat juga dapat terikat dan terbuang dengan sendirinya bersama kotoran.

Melancarkan pencernaan kulit pisang mengandung serat yang cukup, sehingga dapat melancarkan proses pencernaan tubuh. 4) Meningkatkan daya tahan tubuh serat kulit pisang, kaya akan antioksidan yang dapat meningkatkan daya tahan tubuh. Antioksidan merupakan sebutan untuk zat yang berfungsi melindungi tubuh dari serangan radikal bebas. Yang termasuk ke dalam golongan zat antioksidan antara lain, vitamin, polipenol, karotin, dan mineral. Sedangkan antioksidan yang terdapat dalam kulit pisang yaitu vitamin B, dan vitamin C. Aktifitas lingkungan yang dapat memunculkan radikal bebas yaitu polusi, asap rokok, dll. Antioksidan mencegah terjadinya penyakit dengan cara menekan kerusakan sel yang terjadi akibat proses oksidasi radikal bebas.

Kripik adalah makanan ringan bersifat renyah yang berasal dari produk olahan hasil pertanian serta tahan disimpan dalam waktu yang lama. Selain itu, keripik mengandung lemak yang tinggi dan disenangi masyarakat luas. Kriteria umum keripik adalah mengandung karbohidrat, berpenampilan kering, bila dikomsumsi menimbulkan bunyi, dan mudah patah. Pada pembuatan keripik terjadi proses pengeringan dengan tujuan untuk menambah daya tahan pada bahan makanan dan mempertahankan mutu. Pengeringan adalah suatu cara untuk mengeluarkan atau menghilangkan sebagian air yang terkandung dalam bahan makanan dengan menggunakan cahaya matahari. Kandungan air tersebut dikurangi sampai batas dimana mikroorganisme tidak dapat tumbuh lagi didalamnya.

Kripik kulit pisang adalah kripik yang dibuat dari bahan baku yang kulit pisang, yang dilumuri dalam adonan tepung tapioka dan tepung beras dengan penambahan bumbu rempah dan telur serta melalui proses penggorengan yang nantinya setelah proses penirisan minyak hasil penggorengan, kripik akan diaduk dengan bubuk cabe yang telah dikeringan dengan penambahan sejumlah garam halus.

Kripik kulit pisang ini selain gurih rasanya juga memiliki rasa pedas sehingga diharapkan nantinya menjadi kemilan favorit di tiap waktu yang tidak kalah bersaing karena harganya terjangkau sehingga diharapkan teknologi ini dapat membuka wawasan untuk produksi pangan skala rumah tangga dengan bahan baku yang mudah di dapat yaitu kulit pisang.

\section{KOMPOSISI KIMIA KULIT PISANG}

Buah pisang banyak mengandung karbohidrat baik isinya maupun kulitnya. Pisang mempunyai kandungan khrom yang berfungsi dalam metabolisme karbohidrat dan lipid. Khrom bersama dengan insulin memudahkan masuknya glukosa ke dalam sel-sel. Kekurangan khrom dalam tubuh dapat menyebabkan gangguan toleransi glukosa. Umumnya masyarakat hanya memakan buahnya saja dan membuang kulit pisang begitu saja. Di dalam kulit pisang ternyata memiliki kandungan vitamin $\mathrm{C}, \mathrm{B}$, kalsium, protein, dan juga lemak yang cukup. Hasil analisis kimia menunjukkan bahwa komposisi kulit pisang banyak 
mengandung air yaitu $68,90 \%$ dan karbohidrat sebesar $18,50 \%$. Komposisi zat gizi kulit pisang dapat dilihat pada tabel 1 .

Tabel 1. Komposisi Zat Gizi Kulit Pisang per 100 gram bahan

\begin{tabular}{|c|l|r|}
\hline No. & \multicolumn{1}{|c|}{ Zat Gizi } & \multicolumn{1}{|c|}{ Kadar } \\
\hline 1 & Air (g) & 68,90 \\
2 & Karbohidrat (g) & 18,50 \\
3 & Lemak (g) & 2,11 \\
4 & Protein (g) & 0,32 \\
5 & Kalsium (mg) & 715.00 \\
6 & Fosfor (mg) & 117.00 \\
7 & Zat besi (mg) & 1,60 \\
8 & Vitamin B (mg) & 0,12 \\
9 & Vitamin C (mg) & 17,50 \\
\hline
\end{tabular}

Sumber: Balai Penelitian dan Pengembangan Industri, Jatim, Surabaya (1982).

Karbohidrat atau Hidrat Arang yang dikandung oleh kulit pisang adalah amilum. Amilum atau pati ialah jenis polisakarida karbohidrat (karbohidrat kompleks). Amilum (pati) tidak larut dalam air, berwujud bubuk putih, tawar dan tidak berbau. Pati merupakan bahan utama yang dihasilkan oleh tumbuhan untuk menyimpan kelebihan glukosa (sebagai produk fotosintesis) dalam jangka panjang. Hewan dan manusia juga menjadikan pati sebagai sumber energi yang penting. Amilum merupakan sumber energi utama bagi orang dewasa di seluruh penduduk dunia, terutama di negara berkembang oleh karena di konsumsi sebagai bahan makanan pokok. Disamping bahan pangan kaya akan amilum juga mengandung protein, vitamin, serat dan beberapa zat gizi penting lainnya (Johari dan Rahmawati, 2006).

\section{BAHAN - BAHAN PEMBUATAN KRIPIK KULIT PISANG PEDAS}

Pada pembuatan kripik kulit pisang ini maka dipergunakan bahan baku yakni kulit pisang, tepung tapioka, tepung beras, telur, garam, bumbu yang sudah dihaluskan dan bubuk cabai kopay kering asin hasil penelitian sebelumnya. Disamping itu juga digunakan bahan tambahan lainnya yakni : kapur sirih, Calsium diklorida $\left(\mathrm{CaCl}_{2}\right)$ dan Natrium metabisulfit.

Sebelum membuat keripik kulit pisang, hal yang harus diperhatikan adalah pemilihan / sortasi bahan baku yang berkualitas sehingga hasil yang diperoleh akan baik. Pada pembuatan keripik kulit pisang diperlukan bahan baku adalah kulit pisang kepok yang telah masak dan tidak lembek, karena kulit pisang tersebut mengandung karbohidrat yang cukup tinggi. Selain itu, kulit pisang yang berwarna kuning cerah dan tidak cacat akan mempengaruhi rasa dan warna keripik.

Tepung tapioka adalah tepung yang terbuat dari pati yang diekstrak dengan air dari umbi singkong (ketela pohon). Setelah disaring, bagian cairan dipisahkan dari ampasnya. Cairan hasil saringan tersebut lalu dikeringkan dan digiling sehingga diperoleh butiran pati halus berwarna putih. 
Astawan (2008) menguraikan bahwa tapioka tidak mengandung gluten, dan bersifat larut dalam air, kaya karbohidrat dan energi dengan sedikit lemak dan protein dengan komposisi zat gizi per $100 \mathrm{~g}$ tapioka sebagai berikut : energi $358 \mathrm{kkal}$, protein $0,19 \mathrm{~g}$, lemak total 0,02 g, karbohidrat 88,69 g, serat pangan $0,9 \mathrm{~g}$, kalsium $20 \mathrm{mg}$, besi 1,58 $\mathrm{mg}$, magnesium $1 \mathrm{mg}$, fosfor $7 \mathrm{mg}$, kalium $11 \mathrm{mg}$, natrium $1 \mathrm{mg}$, seng 0,12 $\mathrm{mg}$, tembaga $0,02 \mathrm{mg}$, mangan $0,11 \mathrm{mg}$, selenium $0,8 \mathrm{mg}$, asam folat $4 \mu \mathrm{g}$. Selanjutnya beliau menjabarkan bahwa tapioka yang baik adalah tapioka yang berwarna putih, dengan KA yang rendah, berasal dari serat dan kayu ubi yang umurnya kurang dari 1 tahun, dan daya rekat tapiokanya tinggi.

Selanjutnya adalah tepung beras sebagai bahan dasar. Tepung beras secara umum digunakan sebagai bahan dasar atau campuran pada pengolahan panganan. Adapun tepung beras yang digunakan pada pembuatan kripik kulit pisang ini adalah tepung beras putih.

Tepung beras putih dibuat dari beras yg digiling/dihaluskan. Warnanya putih, bila diraba dengan jari, tepung beras akan terasa lebih lembut dan halus dibandingkan dengan tepung ketan. Beras yang berwarna putih agak transparan karena hanya memiliki sedikit aleuron, dan kandungan amilosa umumnya sekitar 20\%. Tepung Beras mengandung energi sebesar 364 kilokalori, protein 7 gram, karbohidrat 80 gram, lemak 0,5 gram, kalsium 5 miligram, fosfor 140 miligram, dan zat besi 1 miligram. Selain itu di dalam Tepung Beras juga terkandung vitamin A sebanyak 0 IU, vitamin B1 0,12 miligram dan vitamin $\mathrm{C} 0$ miligram. Hasil tersebut didapat dari melakukan penelitian terhadap 100 gram Tepung
Beras, dengan jumlah yang dapat dimakan sebanyak $100 \%$.

Hariyadi (2005) mengatakan bahwa tepung beras mempunyai sifat fisik dan sensori yang khas sehingga mempunyai potensi sebagai ingredinet pangan. "Satu sifat penting dari tepung beras adalah nonallergenic. Sehingga secara khusus produk ini dapat dimanfaatkan untuk mensubstiutsi tepung lain, khususnya tepung terigu. Hal ini, tegasnya, sangat bermanfaat bagi orang yang alergi terhadap gluten dan produk-produk tepung terigu lainnya. Selain itu hasil ekstraksi tepung beras ini dapat dibuat berbagai macam produk pangan yang bermanfaat. Misalnya, pasta, keripik (chips) dan produk makanan ringan lainnya, termasuk produk sereal yang dikonsumsi saat sarapan.

Sementara untuk mendapatkan tepung beras yang berkualitas, bisa diperoleh dari penggilingan beras pecah atau patah, yaitu beras yang memiliki ukuran kurang dari biji beras utuh. Beras pecah atau patah ini, sebaiknya dipisahkan terlebih dahulu. Sehingga nantinya akan diperoleh beras kepala (utuh) dengan mutu yang baik. Kalau dipisahkan akan diperoleh tepung beras dengan berbagai keunggulan yang bisa dipasarkan dengan nilai ekonomi yang lebih tinggi.

Pada pembuatan kripik kulit pisang pedas ini juga menggunakan telur sebagai campuran adonan tepung tapioka, tepung beras putih dan bumbu yang telah dihaluskan (bawang putih, ketumbar, garam, dan laos putih). David (2013) menjabarkan bahwa fungsi telur pada adonan ini adalah untuk membangun kerangka serta memberi warna pada kripik yang dihasilkan. Selain itu telur yang digunakan akan menambah nilai gizi dari kripik yang 
dihasilkan. Sedangkan bumbu yang digunakan tidak lain bertujuan untuk menciptakan rasa tersendiri dari kripik kulit pisang yang dihasilkan.

Pada pembuatan kripik kulit pisang dengan rasa pedas ini juga digunakan garam yodium sesuai ketentuan SNI 01 - 3556 - 2000. Garam yang pertama kali diperkenalkan oleh bangsa Eropa ini mengandung ion-ion sodium dan klorida yang merupakan zat gizi penting, menjadikan garam salah satu zat paling pokok bagi manusia. Selain itu, rasa asinnya adalah salah satu dari keempat rasa dasar. Karena fungsinya sebagai bahan pengawet dan penyedap rasa, maka garam juga menjadi sumber mineral yang cukup berharga (Sinaga, 2004).

Garam dapur dalam keadaan murni tidak berwarna, tetapi kadangkadang berwarna kuning kecoklatan yang berasal dari kotoran-kotoran yang ada didalamnya. Air laut mengandung \pm $3 \%$ garam dapur. Garam dapur sebagai penghambat mikroba, sering digunakan untuk mengawetkan ikan dan juga bahan-bahan lain. Penggunaannya sebagai pengawet minimal sebaanyak 5\% - 20\% (Trimargono et al., 2003).

Penambahan Kapur pada bahan pangan bertujuan sebagai pengeras dalam upaya memperkeras produk keripik, buah kalengan atau dalam pembuatan pikel. Penggunaan bahanbahan tersebut harus sesuai dengan pemakaian dan dosis penggunaannya, karena penambahan kapur berpengaruh pada kesehatan jika memberikan dosis berlebih pada bahan pangan.

$\mathrm{CaCO}_{3}$ (kapur) $+2 \mathrm{H}_{2} \mathrm{O}$ à $\mathrm{Ca}(\mathrm{OH})_{2}+$ $\mathrm{H} 2 \mathrm{CO}_{3}$

Bahan kapur terdiri atas suspensi kasar dan kelarutan kolodial dari kalsium hidroksida atau kalsium sulfat. Bersifat anhidrat atau pentahidrat. Kelarutannya dalam air hanya $0,12 \%$ pada suhu $25^{\circ} \mathrm{C}$

Selanjutnya penggunaan $\mathrm{CaCl} 2$ yang berbentuk kristal dan berwarna putih yang digunakan dalam pengolahan bahan pangan untuk memperkuat tekstur agar tetap terlihat keras. (Suryani dkk, 2004).

Pengolahan bahan makanan yang berasal dari tumbuhan sering menghasilkan tekstur yang berubah menjadi lunak. Hal ini akibat perlakuan pada saat proses pengolahan atau pemanasan. Saat pemanasaan, komponen dinding sel buah dan sayuran mengalami proses penguraian. Akibatnya jaringan menjadi lunak. Untuk mempertahankan kerenyahan pangan olahan, maka dapat dilakukan penambahan zat pengeras pada saat pengolahan (Fatah dan Bachtiar, 2004 cit Tambunan 2006).

Lebih lanjut dikatakan bahwa perendaman dengan larutan $\mathrm{CaCl} 2$ berfungsi untuk menguatkan tekstur buah atau sayuran yang diolah menjadi produk olahan sehingga lebih kuat dan renyah. Perubahan ini disebabkan adanya senyawa kalsium dalam kapur yang berpenetrasi ke dalam jaringan buah atau sayuran. Akibatnya struktur jaringan buah atau sayuran menjadi lebih kompak berkat adanya ikatan baru antara kalsium dan jaringan dalam buah atau sayuran. Selain itu, penambahan $\mathrm{CaCl} 2$ juga bermanfaat untuk menetralkan warna coklat yang sering muncul pada buah atau sayuran, baik setelah pengupasan maupun setelah perendaman dengan bahan kimia.

Menurut Indeswari (1991) cit Tambunan (2006), penambahan garamgaram kalsium yang berlebihan dapat menghalangi pematangan buah tiga kali lipat pematangan normal. Dengan 
terhalangnya proses pematangan maka tekstur buah tidak menjadi lunak ataupun lembek. Selain itu keuntungan dari kalsium adalah kalsium tidak bersifat toksid atau beracun.

Keefektifan garam kalsium tergantung pada kandungan pektin yang ada pada buah dan sayuran. Selain itu garam kalsium pemakaiannya tergantung juga pada ada atau tidaknya zat-zat pengikat kalsium, misalnya ion oksalat, ion sitrat dan lain-lain.

Penggunaan Natrium metabisulfit atau dikenal dengan istilah sulfurisasi adalah perlakuan dengan penambahan SO2 yang dilakukan pada bahan sebelum dikeringkan. Bahan kimia yang dapat dijadikan sumber sulfur dioksida adalah senyawa-senyawa sulfit seperti Natrium dan Kalium bisulfit atau metabisulfit.
Menurut Poesoedarmo dan Oetama (1979) cit Hendri (1990), cara sulfuri dapat dilakukan dengan perendaman dalam larutan sulfur dioksida yang biasanya digunakan sebagai zat penghambat aktifitas enzim fenolase untuk bahan-bahan yang dikeringkan .

Pengaruh sulfur dioksida dalam mencegah reaksi pencoklatan adalah karena sulfur dioksida dapat mereduksi ikatan disulfida ( $-\mathrm{S}=\mathrm{S}$ - ) dari protein enzim sehingga akan menghambat kerja enzim. Natrium bisulfit bereaksi dengan gugus karbonil pada aldehid, keton atau gula pereduksi membentuk asam hidrosulfonat, seperti diuraikan pada Gambar 2 (Joslyn dan Biaverman, 1949 cit Hendri , 1990) :

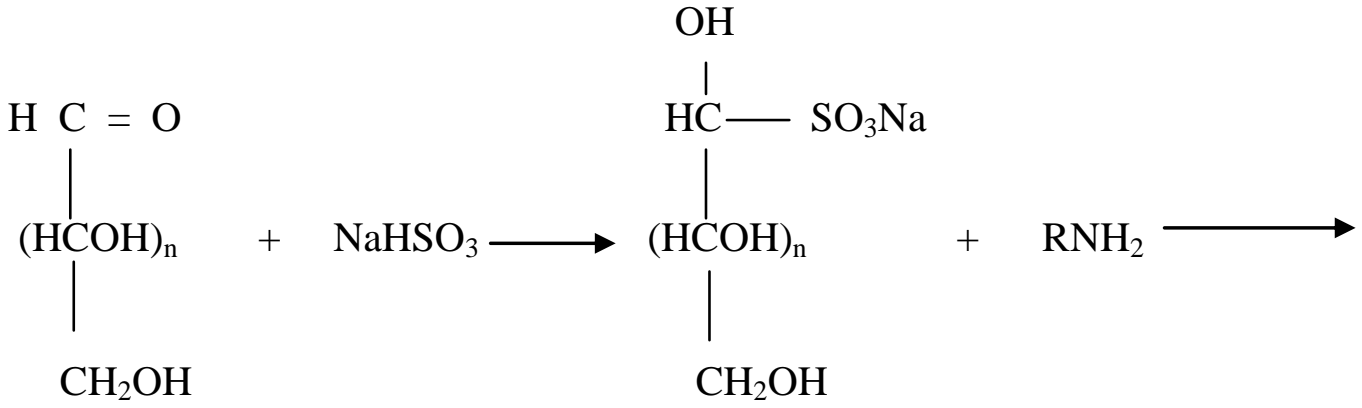

Glukosa

Senyawa adisi bisulfit<smiles>C1CCCC1</smiles>

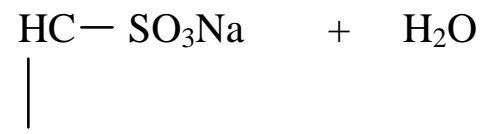<smiles>CC(C)O</smiles>

$\mathrm{CH}_{2} \mathrm{OH}$

Asam hidro-sulfonat

Gambar 1. Reaksi kimia antara glukosa dengan natrium metabisulfit membentuk asam hidro-sulfonat dan air 
Semakin tinggi konsentrasi Natrium bisulfit yang digunakan akan terjadi pengikatan oleh komponen organik dan terjadi penurunan aktifitas enzim, sehingga kandungan gula lebih tinggi (Priyanto, 1987 cit Hendri , 1990).

BPS (1978) cit Hendri (1990) menguraikan bahwa garam Natrium bisulfit yang dapat dipergunakan antara lain ; berbentuk tepung, mempunyai sifat higroskopis, berwarna putih, berbau khas seperti gas sulfur dioksida dengan berat jenis 1,48 dan larut dalam air 3,5 ml air dingin. Batas maksimal penggunaan dalam bahan yang dikeringkan yang disetujui " Food Drug Administration “ adalah 2000 - 3000 ppm (Winarno, 1980).

Gould \& Russell (1991) cit Paramita (1999) menyatakan bahwa batas maksimum pemakaian sulfit dalam buah yang dikeringkan adalah 100 2000 ppm. Direktorat Pengawas Makanan dan Minuman (1987) memberi batas maksimum penggunaan sulfit pada sayuran kering adalah sebanyak 2000 ppm.

Natrium metabilsufit yang diperdagangkan berbentuk kristal. Pemakaiannya dalam pengolahan bahan pangan bertujuan untuk mencegah proses pencoklatan pada bahan sebelum diolah, menghilangkan bau dan rasa getir terutama pada ubi kayu serta untuk mempertahankan warna agar tetap menarik.

Natrium metabisulfit dapat dilarutkan bersama-sama bahan atau diasapkan. Prinsip pengasapan tersebut adalah mengalirkan gas $\mathrm{SO}_{2}$ ke dalam bahan sebelum pengeringan. Pengasapan dilakukan selama \pm 15 menit. Maksimum penggunaannya sebanyak 2 gram $/ \mathrm{kg}$ bahan. Natrium metabisulfit yang berlebih akan hilang sewaktu pengeringan (Trimargono, Suryati dan Hartinah, 1993).

Buckle et al. (1987) menegaskan bahwa natrium metabisulfit dapat dipakai sebagai bahan pengawet tetapi tidak diperkenankan pemakaiannya dalam daging atau bahan pangan lain yang merupakan sumber vitamin $B_{1}$.

Lebih lanjut beliau menguraikan bahwa kemampuan garam sulfit yang larut untuk melindungi diskolorasi dari bahan pangan dapat dijumpai dalam berbagai aplikasi seperti dalam perlakuan terhadap irisan apel yang dibuat, kentang yang dikupas dan buahbuahan dan sayuran lainnya untuk mencegah pencoklatan.

Pada akhir proses pengolahan nantinya, kripik kulit pisang hasil gorengan akan diaduk dengan bubuk cabai kopay kering asin terbaik hasil perlakuan penelitian sebelumnya dengan cara memasukan bubuk cabai tersebut ke dalam baskom yang bertutup yang kemudian dimasukan kripik kulit pisang yang telah ditiriskan setelah penggorengan, lalu baskom ditutuk dan diaduk dengan cara menggongkan atau memutar baskom ke atas atau ke bawah secara cepat, atau dengan arah memutarmutar dengan tujuan agar bubuk cabai akan menempel merata pada seluruh permukaan kripik cabai.

Menurut Lukmana (2004) cabai mengandung kurang lebih $1.5 \%$ rasa pedas yang terutama disebabkan oleh kandungan capcaisin dan dihidrocapcaisin. Kandungan homocapcaisin dan homodihidro capcaisin terdapat dalam konsentrasi sangat kecil.

Lebih lanjut beliau mengatakan bahwa pada saat ini, telah ditemukan kandungan karatenoid (capsanthin, capsorubin, carotene dan lutein), lemak 
(9-17\%), protein $(12-15 \%)$, vitamin A dan $C$, serta sejumlah kecil minyak menguap. Kandungan dala minyak menguap mencapai 125 komponen dan 24 di antara komponen tersebut sudah dapat diidentifikasi.

Tandon, Dravid dan Siddapa (1962) cit Adinata (2005) menyatakan bahwa komponen pemberi rasa pedas (capsainoids) sebagian besar terdapat dalam perikarp $(89,20 \%)$, di bagian biji $10,80 \%$ dan tidak ditemukan pada bagian tangkai.

Adapun karakteristik dari bubuk cabai kopay kering asin tersebut adalah : mengandung kadar air 10,04\%, rendemen $22,60 \%$, kadar capcaisin $23 \%$, warna $58,36 \%$ dari standar, kandungan 8 karoten sebesar 2.390,95 $\mu \mathrm{g} / 100 \quad \mathrm{~g}$ bahan, daya rehidrasi $56,49 \%$, waktu rehidrasi 11,62 detik,pertumbuhan mikroba yang dapat diabaikan, Vitamin C $56,49 \mathrm{mg} / 100 \mathrm{~g}$ bahan dengan tingkat kepedasan 100.000 SHU.

\section{PERALATAN PENGOLAHAN}

Dalam proses pengolahan kulit pisang menjadi kripik kulit pisang pedas digunakan peralatan sebagai berikut ; pisau,talenan, baskom, ayakan, satu set penggorengan, vakum heat sealer, kompor gas dan perlengkapannya, toples ukuran besar.

Pisau digunakan untuk memotong kulit pisang segar dan jenis pisau yang digunakan adalah pisau ukuran sedang dan memiliki mata pisau yang melengkung. Hal tersebut untuk tidak lain bertujuan untuk memudahkan proses pernotongan.

Saat proses pengolahan, baskom digunakan untuk proses pencucian, perendaman saat blanching dan perendaman dengan larutan $\mathrm{CaCl}_{2}$, pengadukan adonan, dan pencampuran kulit pisang dengan adonan. Sedangkan ayakan berguna untuk memisahkan antara kulit pisang dengan sisa-sisa tepung adonan yang telah diberi bumbu yang masih menernpel.

Kompor gas dan perlengkapannya digunakan untuk menggoreng kulit pisang yang telah diberi adonan berbumbu. Kompor gas dipilih dengan tujuan untuk mendapatkan pemanasan yang stabil dan merata pada proses penggorengan.

Selanjutnya, satu set penggorengan digunakan untuk menggoreng kulit pisang yang telah dilumuri dengan adonan. Selanjutnya manual heat sealer adalah mesin pengemas yang digunakan memakai prinsip pemanasan setempat pada bahan dasar yang akan disatukan.

Dan terakhir adalah toples ukuran besar yang bertutup yang digunakan sebagai wadah sementara untuk mengaduk kripik kulit pisang yang telah melalui proses penggorengan dan penirisan minyak dengan bubuk cabai yang telah dipersiapkan untuk memberi sentuhan akhir proses sehingga dihasilkan kripik kulit pisang pedas. Disamping itu toples besar bertutup digunakan untuk menyimpan keripik kulit pisang pedas sebelum pengemasan.

TAHAPAN PROSES PENGOLAHAN

A. Persiapan Bahan Baku

1. Kulit pisang

Kulit pisang kepok yang diperoleh dari tempat-tempat penjualan gorengan disortasi dan dipilih kulit pisang kepok yang telah masak dan tidak lembek, karena kulit pisang tersebut mengandung karbohidrat yang cukup tinggi. Selain itu, kulit pisang yang berwarna kuning cerah 
dan tidak cacat akan mempengaruhi rasa dan warna keripik.

B. Persiapan bahan kimia

1. Larutan air kapur

Larutan kapur dibuat dengan mengambil setengah sendok teh kapur ke dalam satu liter air. Kulit pisang direndam dalam larutan air kapur tersebut selama 20 menit. Perendaman dengan air kapur ini bertujuanuntuk mempuat keripik kulit pisang menjadi terasa lebih renyah.

\section{Larutan blanching}

$\mathrm{NaHSO}_{3}$ (Natrium Bisulfit) 2000 ppm dilarutkan dalam air dengan suhu berkisar $82^{\circ} \mathrm{C}-93^{\circ} \mathrm{C}$.

\section{Kalsium diklorida $\left(\mathrm{CaCl}_{2}\right)$}

Kristal $\mathrm{CaCl}_{2}$ yang berwarna putih dan diperoleh dari laboratorium, dilarutkan dalam air sehingga kadar $\mathrm{CaCl}_{2}$ menjadi $0,2 \%$, yang nantinya digunakan untuk merendam sementara cabai keriting yang akan diolah.

4. Larutan garam $(\mathrm{NaCl})$

Garam dapur dalam keadaan murni tidak berwarna dilarutkan dalam air dengan konsentrasi $7,5 \%$. Kemudian larutan ini nantinya akan digunakan untuk merendam cabai sebelum dikeringkan. Perendaman dilakukan selama 15 menit.

C. Proses pengolahan kripik kulit pisang itu sendiri

1. Kulit pisang hasil sortasi dibersihkan dari kotoran-kotoran yang menempel, kemudian dicuci di air yang mengalir

2. Setelah itu kulit pisang ditiriskan dari air pencucian tadi, lalu dipotong dengan ukuran memanjang.
3. Kulit pisang yang telah dipotong kemudian direndam dengan air kapur selama 20 menit.

4. Perendaman kulit pisang yang telah bersih dilakukan dalam larutan blanching selama 5 menit, kemudian kulit pisang dicelupkan ke dalam air dingin untuk menjaga supaya kulit pisang tadi jangan sampai terlalu masak, lalu ditiriskan.

5. Kulit pisang yang telah ditiriskan tadi lalu direndam dalam larutan $\mathrm{CaCl} 20,2 \%$ selama 30 menit, kemudian cabai dibilas dengan air bersih dan ditiriskan kembali.

6. Kulit pisang hasil tirisan kemudian dijemur kulit pisang hingga kering (8 jam) .

7. Wadah baskom diisi dengan campuran tepung beras dan tepung tapioka dengan perbandingan 1: 1 .

8. Sedangkan bumbu yang telah dipersiapkan dengan cara digiling dengan menghaluskan bawang putih, garam, ketumbar dan laos putih. Setelah halus bumbu tersebut dicampurkan dengan telur. Usahakan telur bercampur merata dengan bumbu, campuran tepung beras dan tepung tapioka dimasukkan dan dicampur sampai merata.

9. Kulit pisang dimasukkan dalam adonan tepung kemudian diayak agar terpisah dengan tepungnya.

10. Kulit pisang yang sudah terpisah dengan tepung lalu digoreng dalam minyak yang sudah dipanaskan terlebih dahulu.

11. Setelah setengah matang, kulit pisang ditiriskan dan didiamkan selama I hari: lalu ulangi proses penggorengnya sampai matang. 
12. Kripik kulit pisang yang telah matang lalu ditiriskan sampai sisa minyak yang masih menempel hilang.

13. Kemudian dengan bantuan toples yang bertutup, bubuk cabe kriting yang telah mengalami perlakuan penggaram dengan kadar 7,5\% dimasukkan ke dalam toples, berikutnya kripik kulit pisang yang telah ditiriskan dari minyak dimasukkan juga ke dalam toples, lalu toples ditutup dan kemudian digoncang-goncangkan untuk menempelkan bubuk cabai ke seluruh permukaan kripik kulit pisang tersebut.

14. Kemudian kripik dikemas dengan menggunakan kemasan plastik kaca (PP) yang kemudian dikemas dengan menggunakan vakum heat sealing sehingga kripik kulit pisang terkemas dalam kemasan yang hampa udara. Hal ini bertujuan untuk menjaga kerenyahan kripik yang dihasilkan.

Diagram Alir Pemanfaatan Kulit Pisang Menjadi Kripik Kulit Pisang Pedas

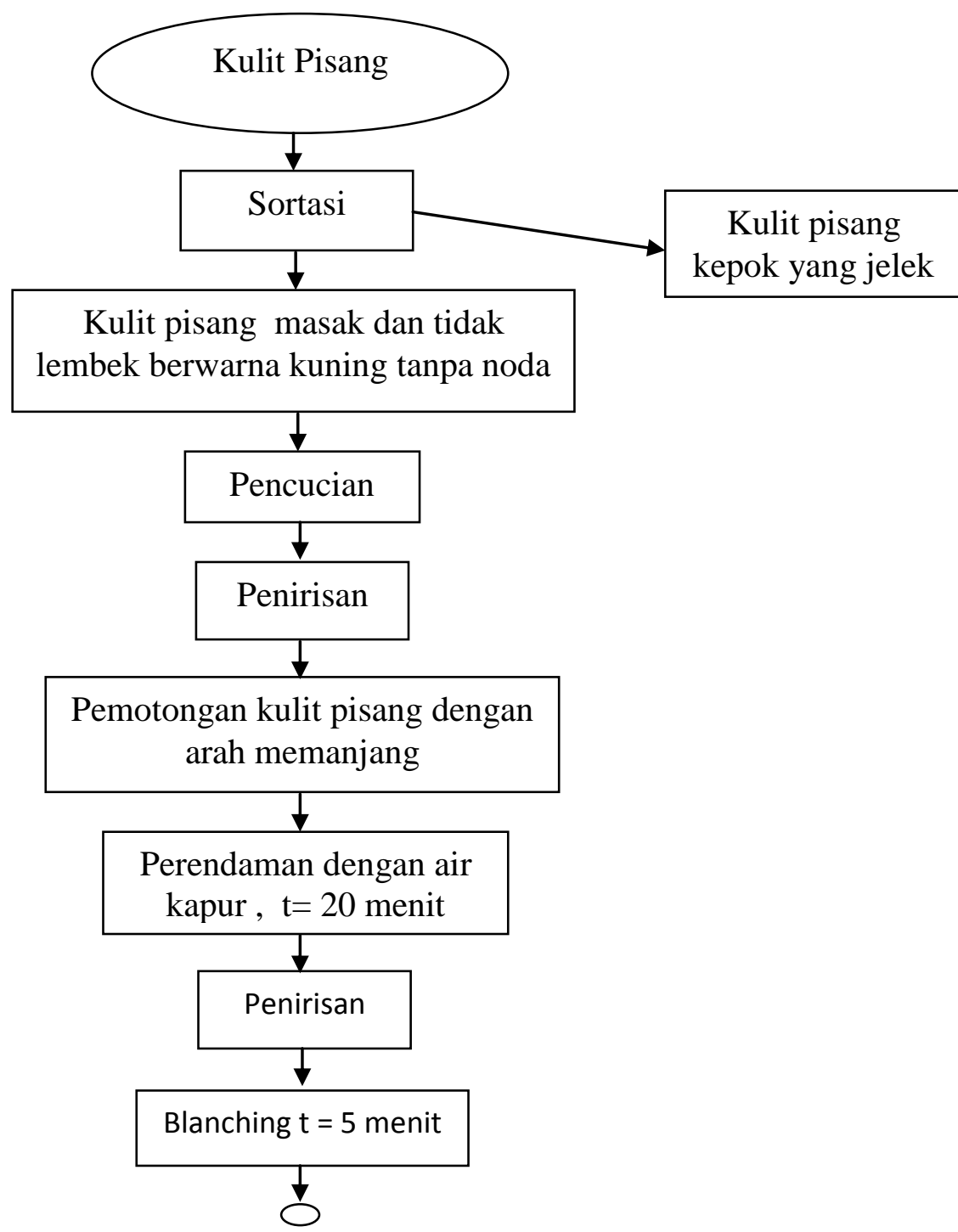




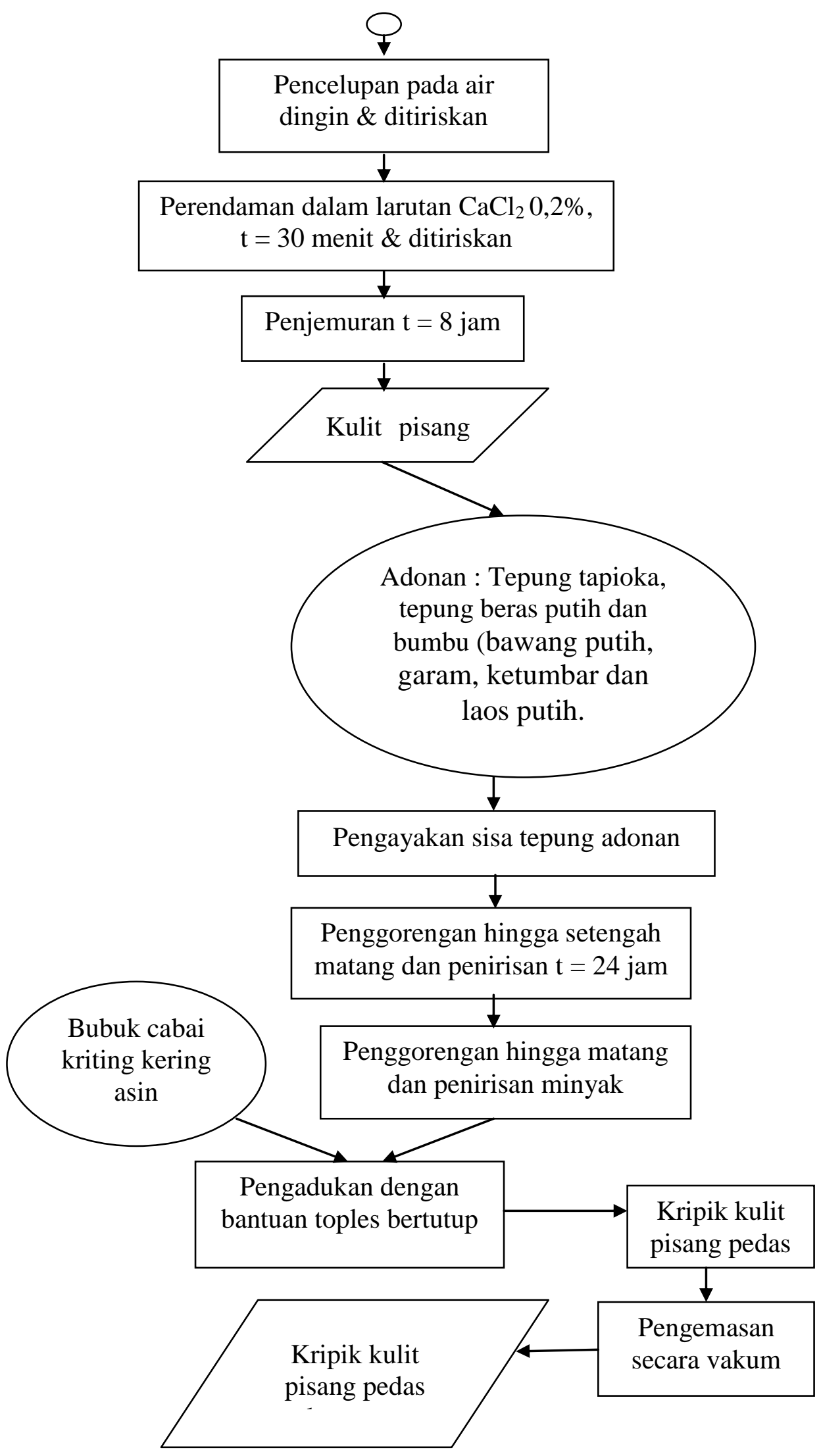




\section{KESIMPULAN}

Kulit pisang selama ini hanya terbuang dan menjadi limbah ternyata masih mengandung zat gizi yang cukup bahkan dapat menjadi terapi untuk penyakit-penyakit tertentu. Agar zat gizinya tidak terbuang dan khasiat dari kulit pisang itu sendiri bagi kesehatan dapat dinikmati oleh masyarakat, perlu rasanya membuat suatu panganan / olahan dengan berbahan baku kulit pisang ini. Dengan sedikit teknologi dan biaya ternyata kulit pisang yang diolah menjadi kripik pisang pedas dapat diterima dan diminati oleh masyarakat. Disamping rasamya yang gurih, pedas dan renyah yang diterima masyarakat, karena produk ini merupakan pangan cemilan yang kering dan dikemas sedemikian rupa, maka daya simpannya pun lama sehingga usaha yang nantinya berkembang dikalangan industri rumah tangga tidak ragu untuk memproduksinya menimbang daya tahan produk.

\section{SARAN}

Pengolahan industri berbasis limbah buah pisang ini sebaiknya menjadi basis atau diterapkan sebagai usaha skala rumah tangga dengan mempertimbangkan modalnya murah, mudah di dapat, produk yang dihasilkan tahan lama dan diminati oleh masyarakat. Pengolahan kripik kulit pisang ini pun nantunya bisa divariasikan rasanya, misalnya menjadi kripik kulit pisang manis, asin, rasa coklat dll.

\section{DAFTAR PUSTAKA}

Anonymous. 1992. Daftar Komposisi Bahan Makanan. Direktorat Gizi, Departemen Kesehatan
Anonymous. 2008. Data Produksi

Hortikultura. Basis Data

Pertanian. Departemen Pertanian.

Http://www.deptan.go.id

diakses 8 juni 2008.

Antarlina, SS., H. Dj. Noor, S. Umar dan I. Noor. 2005. Karakteristik Buah Pisang Lahan Rawa Lebak Kalimantan Selatan serta Upaya Perbaikan Mutu Tepungnya. J.Hort. 15(2):140-150.

Andiga, H . 2013. Manfaat Penambahan Kapur pada Buahan Pangan. htpp://wwww.asalkamutauaja.blo gspot.com/, diunduh tanggal 7 Maret 2013

Astawan dan Wahyuni. 1991. Teknologi Pengolahan Pangan Nabati Tepat Guna. IPB Press. Bogor

Badan Pusat Statistik, 2011. INHIL dalam Angka. BPS 2011 Kabupaten Indragiri Hilir.

David, M, 2013. Mengenal fungsi Bahan Baku Kue dan Roti. htpp://resepmasakan kulinersblogspot.com/, diunduh tanggal 26 Juli 2013-10-09.

Hariyadi, P. 2005. htpp://wwww. republika.co.id/, diunduh tanggal 27 Maret 2006

Hendri, 1990. Pengaruh Tingkat Kematangan Nenas (Ananas comosus Merr) dan Sulfurisasi Terhadap Beberapa Sifat Kimia dan Organoleptik Nenas Kering. (Skripsi). Fakultas Pertanian Universitas Andalas Padang.

Komunitas Edukasi dan Jaringan Usaha, 2012. Isi Kandungan Gizi Tepung Beras . htpp://keju blogspot.com/, diunduh tanggal 13 Desember 2013 
Rismunandar. 1990. Bertanam Pisang. C.V. Sinar Baru. Bandung

Tambunan, S.E.W. 2006. Pengaruh

Lama Penundaan Pengolahan dan Perendaman dengan larutan $\mathrm{CaCl} 2$ Terhadap Mutu Manisan Kering Labu Siang (Sechrum edule (Jacq.) Swartz. (Skripsi). Fakultas Pertanian Universitas Andalas Padang.

Winarno, G, Fardiaz, S dan Fardiaz, D. 1980. Pengantar Teknologi Pangan. PT.Gramedia. Jakarta. 